319 BERIT MERETE KJÆRULFF

Ph.d.-studerende

Institut for Kommunikation og Kultur, Aarhus Universitet

\title{
DE GLEMTE DRØMMES HISTORIE
}

Bertel Nygaard

KÆRLIGHEDENS SAMFUND

Romantiske utopier i

1800-tallets Danmark

Aarhus Universitetsforlag, Aarhus, 2016

Den danske guldalder kategoriseres ofte som en politisk stillestående periode. Mens revolutioner skabte gennemgribende samfundsomvæltninger $i$ andre europæiske lande - går opfattelsen - var de fleste danskere jævnt tilfredse med at bevare deres gamle enevælde. Det varede ved, indtil stemningen over for monarkiet vendte, begyndende med Stænderforsamlingernes oprettelse i 1830'erne og til Frederik VII i 1848 fredeligt gik med til at give landet sin grundlov. Flere historieforskere er dog ved at rykke ved dette noget endimensionelle billede af guldalderens politiske landskab. De arbejder på at fremlæse glemte politiske tanker og ideer, der har stået i skyggen af de mere succesrige bevægelser, som endte med forme samfundet, og derfor naturligvis har sat deres præg på historieforskningen. Rasmus Glenthøj er en af de forskere, der arbejder på at gentænke perioden. Han har blandt andet forsket i politiske grupperinger op mod og efter 1848 med henblik på at nuancere forståelsen af de nationalliberale. Sammen med Morten 
N. Ottosen arbejder han på at tolke skandinavismen på ny og tilgå den som et seriøst politisk projekt. Michael Bregnsbo undersøger den sene enevælde fra en ny vinkel. Han argumenterer for, at det mod midten af 1800-tallet var blevet et utidssvarende system, der i et forsøg på at overleve approprierede liberale ideer og retorik for at kunne tilbyde liberalismens fordele uden dens bagsider. Steen Bo Frandsen har med sit arbejde om helstaten og hertugdømmerne argumenteret for, at helstaten bør tages mere seriøst og må opfattes som et validt alternativ til den nationalstat, Danmark endte med at udgøre.

Dermed er et mere multifacetteret billede af Danmarks politiske tilstand i 1800-tallets begyndelse og midte ved at tegne sig. Denne nye fremstilling giver også plads til vigende eller fejlslagne politiske projekter, som ikke kom til at karakterisere samfundet for eftertiden, men dog var en del af samtiden og en forudsætning for at forstå denne. Bertel Nygaards bog Kærlighedens samfund. Romantiske utopier i 1800-tallets Danmark er et sådant forsøg på at fremskrive glemte politiske strømninger. I bogen præsenterer han danske utopier, der udtrykker anderledes politiske overbevisninger end de dominerede i perioden. Betegnelsen utopisk bruges ikke til at afskrive de skildrede idealsamfund som umulige og urealiserbare, tværtimod tages deres ideer alvorligt og ses som gyldig kritik af samtiden og håb for fremtiden. Nygaards bog er centreret om et glemt utopisk skrift af kontoristen David Frederik Spichmann og kommunistiske ideer fremsat af filosofiprofessoren F.C. Sibbern, begge fra 1840'erne. De to skribenter skriver sig op mod periodens dominerende politiske overbevisninger gennem deres skildringer af tænkte socialistiske og kommunistiske idealsamfund. Socialistiske og kommunistiske ideer var på dette tidspunkt ved at dukke op flere steder i Europa, og Nygaard eftersporer i bogen de danske utopiers relationer til udenlandske politiske tænkere. Herved viser han, hvordan socialistisk og kommunistisk inspirerede tanker bevægede sig på tværs af landegrænser og indtog forskellige særegne udtryk i diverse nationale kontekster.

Bogens sætter som sit formål at skrive politisk kulturhistorie og bidrage til, hvad Nygaard formulerer som "de sociale forhåbningers og drømmes kulturhistorie" (13) 
både $i$ et nationalt og transnationalt perspektiv. Brugen af utopierne som prisme fungerer godt for hans skrivning af de glemte ideers historie, og bogen demonstrerer glimrende utopiernes potentiale i historisk henseende. Den viser, hvordan de med deres alternative ideer åbner for en mere nuanceret forståelse af fortiden. Tilgangen til historien gennem utopierne lader fortiden manifestere sig som en dynamisk størrelse, som ud over de tankestrømninger, der blev dominerende og primært huskes i dag, indeholdt et væld af andre projekter med ideer, som pegede i vidt forskellige retninger. Som Nygaard påpeger i bogen, kan studiet af længsler efter noget andet - selvom de ikke nødvendigvis blev indfriet - give en forståelse af historiske perioder som mere end de forholdsvist afrundede narrativer, de ofte efterfølgende bliver fremstillet som. At anvende glemte utopier til at nuancere opfattelsen af historien er netop noget af det, der lykkes fortrinligt med bogen.

Kærlighedens samfund åbner med en fremstilling af utopiens funktion i romantikken, hvorefter den tegner et samtidsbillede af Danmark op til midten af 1800-tallet. I et koncist kapitel præsenteres læseren for de omvæltninger og nye værdier, der karakteriserede perioden: Den nye markedsøkonomi domineret af kapitalisme, samfundets omstilling fra standsopdeling til borgersamfund, nationalismens fremkomst og enevældens afskaffelse, periodens generelle fornemmelse af overgang og krise samt idealet om det organiske som kontrast til kriseerfaringen. Denne gennemgang danner et solidt afsæt for bogens fremlæsning af utopiske impulser i romantikkens bevægelser og strømninger og fungerer også glimrende til at introducere perioden for udenforstående læsere. Herpå følger et oversigtskapitel over tidlige socialistiske og kommunistiske tanker. Kapitlet præsenterer nogle af de vigtigste strømninger af socialismen og kommunismen og deres fremkomst i tiden op til 1848. Fokus ligger naturligt på dem, der kommer til at få indflydelse på danske forhold, som undersøges i de efterfølgende kapitler. Dette er især saint-simonismen, en socialistisk bevægelse, som bogen senere demonstrerer en væsentlig indflydelseskilde for danske utopier. Saint-simonismens ideer nåede Danmark med efterdønningerne af Julirevolutionen i 1830, der initie- 
rede diskussioner om samfundets udvikling i den danske presse. Danske aviser havde ikke tidligere faciliteret politiske debatter i udtalt grad på grund af bekymring for censur. Saint-simonismen føjede til den allerede eksisterende følelse af krise og omvæltning på grund af bevægelsens alternative ideer om arbejdernes, kvindernes og kroppens frigørelse; emner, som senere blev væsentlige i den kulturelle, sociale og politiske udvikling. Saint-simonismens nye ideer blev anvendt af flere parter og ofte til modstridende formål. Nygaard viser, hvordan bevægelsens tanker lod sig appropriere af forskellige politiske enheder, der kunne bruge saint-simonismen både som ideal og skræmmebillede og til både at understøtte liberale og konservative foretagender.

På baggrund af denne gennemgang præsenterer Nygaard bogens danske utopier. Den første er det lille, hidtil glemte skrift Grundtræk til en fuldkommen lykkelig Stats Organisation i et nyt forhen ubeboet Land skrevet af kontoristen David Frederik Spichmann i 1843. Skriftet, der har form som en lille afhandling, beskriver indretningen af en idealstat for danskere, som påtænker at slå sig ned langt fra Danmark og starte et nyt samfund. Spichmanns ideer antager utopisk karakter ved at beskrive et idealsamfund etableret $i$ et endnu ikke grundlagt land, altså et ikke-sted. Ved denne manøvre omgik skriftet censuren og blev herved i stand til at kritisere danske forhold på tryk. I utopien forbinder Spichmann eksisterende moralske og samfundsmæssige ideer på en særegen måde, som lader ham skildre en alternativ samfundsindretning, der kunne danne afsæt for kritik af samtiden. Hans idealsamfund er kommunistisk og demokratisk uden dog at gøre brug af disse betegnelser, som i samtiden blev opfattet som yderst suspekte. Ordet kommunisme, forklares det, fungerede i perioden som en fælles afgrænsning for samfundsprojekters legitimitet. At udelade begrebet kommunisme lader dermed skriftet fremstille kommunismens indhold i et positivt lys, hvorved kommunismen finder et dansk udtryk. Nygaard indvender selv i bogen, at utopiens meget begrænsede gennemslagskraft i samtiden kan synes at begrænse dens historiske interesse. Han finder i stedet værkets relevans i dets indhold og form, som han læser som et historisk symptom. Utopien kan 
give indblik i, hvilke forhold har kunnet påvirke en nogenlunde almindelig borger til at udvikle kommunistisk inspirerede ideer. Det interessante ved Spichmanns glemte utopi er således dens identificering af problemer i samtiden, dens valg af byggesten til at skabe et ideelt samfund og dens egenartede udtryk for politiske tanker.

Den anden danske utopi, bogen behandler, stammer fra F.C. Sibbern. Fra at have været en solid støtte af enevælden, skiftede Sibbern ved konstitutionens indførelse holdning og blev erklæret kommunist. Han opfattede kommunismen som den sande og naturlige tilstand for mennesket, da han så den som karakteriseret af fællesskab og kærlighed. Nygaard undersøger Sibberns kommunistiske ideer fremsat i indbydelsesskriftet Nogle Betragtninger over Stat og Kirke skrevet i anledning af Frederik VIIs fødselsdag i oktober 1849 og gengivet i den omfattende, ufuldendte utopiske fortælling Meddelelser af Indholdet af et Skrivt fra Aaret 2135 udgivet mellem 1858 og 1872. Som med Spichmann er Nygaards fokus mindre på utopiens indflydelse på den historiske udvikling, men består mere i at udforske Sibberns position mel- lem hans identitet som konservativ enevældestøtte og nytænkende kommunist. Herigennem gives indblik i, hvordan der opstod nye ideer og politiske standpunkter i mødet mellem det gamle og det nye i Danmark midt i 180o-tallet. Bogens sidste kapitler breder perspektivet mere ud. Her udforskes de første bølger af indflydelse på det danske samfund af Marx' ideer om historisk udvikling, social handling og kommunisme, som nåede landet i 1840'erne. Til sidst giver bogen et udsyn mod tiden efter 1849, hvor revolutionerne har ændret vilkårene for utopiske forhåbninger, hvilket har betydet, at utopien nu var kommet til at fremstå mindre relevant. I denne periode kommer ingen nye danske utopier til, men i stedet oversættes udenlandske utopier til dansk. Nygaard undersøger to sådanne, den populære amerikanske Looking Backward, 2000-1887 af Edward Bellamy, som udkommer på dansk i 1889, og News From Nowhere af William Morris fra 1890. Disse utopier danner kontrast til den utopinegligerende fremskridtstro, som fra anden halvdel af 1800-tallet kom til at dominere det politiske forestillingsrum. Det var ikke blot indholdet af utopier, som blev af- 
fejet, men selve det at tage stilling til utopiske forestillinger, selvom de udgør et grundlæggende vilkår for politisk-social forandring. Det er netop denne fortrængning af det utopiske som eksistensbetingelse for politisk udvikling, Nygaard med bogen påpeger, at nutidsmennesket kan blive bevidst om i mødet med romantiske utopiers fremtidsskildringer.

Kærlighedens samfund giver læseren perspektiv på sin egen samtid sideløbende med, at den giver nyt indblik i en væsentlig periode for udformningen af det nuværende Danmark. Bogen viser, at guldalderen langt fra er karakteriseret ved politisk stilstand, men rummer adskillige divergerende ideer om, hvordan samfundet bør indrettes. Den giver et nuanceret billede af romantikken ved også at inkludere de ideer og tanker, som måske ikke blev realiserede, men dog satte præg på perioden. Gennem studiet af utopierne bidrager bogen således til historieforskningen ved at fremskrive de glemte drømmes historie. • 